\title{
Delegated Federalism versus Devolution: Some Insights from the History of Water Pollution Control
}

William L. Andreen

University of Alabama - School of Law, wandreen@law.ua.edu

\section{Recommended Citation}

William L. Andreen, Delegated Federalism versus Devolution: Some Insights from the History of Water Pollution Control, (2009).

Available at: https://scholarship.law.ua.edu/fac_working_papers/323

This Working Paper is brought to you for free and open access by the Faculty Scholarship at Alabama Law Scholarly Commons. It has been accepted for inclusion in Working Papers by an authorized administrator of Alabama Law Scholarly Commons. 


\title{
THE UNIVERSITY OF ALABAMA SCHOOL OF LAW
}

\section{Delegated Federalism Versus Devolution: Some Insights From the History of Water Pollution Control}

\author{
William L. Andreen \\ PREEMPTION CHOICE: The THEORY, LAW, AND REALITY OF \\ FEDERALISM'S CORE QUESTION \\ William W. Buzbee, ed. (Cambridge Univ. Press 2009)

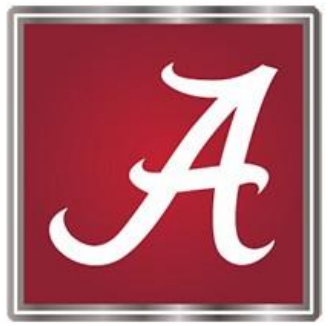 \\ This paper can be downloaded without charge \\ from the Social Science Research Network \\ Electronic Paper Collection: \\ http://ssrn.com/abstract $=1452794$
}




\section{Preemption Choice: The Theory, Law, and Reality of Federalism's Core Question}

Edited by

WILLIAM W. BUZBEE

Emory University School of Law: 


\title{
DELEGATED FEDERALISM VERSUS DEVOLUTION: SOME INSIGHTS FROM THE HISTORY OF WATER POLLUTION CONTROL
}

\author{
William L. Andreen*
}

\begin{abstract}
This paper examines the claim that state and local governments were beginning, prior to the enactment of the Clean Water Act in 1972, to make significant progress in the fight against water pollution. Based on this premise, some have argued that there is good reason to be skeptical about the necessity for continued federal involvement in water pollution control. At their broadest, such scholars use this revisionist history to question other federal environmental statutes' structures as well. The implication of this argument is that the devolution of regulatory authority to the states would not produce lower levels of environmental protection. Thus our present approach to water pollution control - delegated program federalism, a form of cooperative federalism with federal regulatory floors preempting any more lax state regulation, and federal oversight of state delegated programs - is really not necessary from a practical point of view and can be discarded without producing substantial environmental harm.
\end{abstract}

After setting forth the Clean Water Act's approach to delegated federalism, the paper discusses the flawed nature of the data upon which this claim is made. The experience of the 1960s simply does not support the argument in favor of devolution. This does not mean that every state was retrograde in its protection of water quality. The paper, therefore, will also look at the progressive approach taken by some states, while also focusing upon the action of the federal government during the 1960s to improve water quality. Nevertheless, the best evidence we have indicates that water quality was not improving nationwide before the enactment of the Clean Water Act. In contrast to that level of performance, the Clean Water Act has produced considerable progress, progress, however, which would surely be jeopardized should the nation revert to the regulatory paradigm of the 1960s. The story reveals substantial benefits from federal regulation within a structure that preserves room for state participation, creativity, and even greater stringency.

This paper is a preliminary version of a chapter that was published in PREEMPTION CHOICE: THE THEORY, LAW, AND REALITY OF FEDERALISM'S CORE QUESTION (William W. Buzbee, ed., Cambridge University Press, 2009). Please refer to that final, published version for citation purposes.

* Edgar L. Clarkson Professor of Law, The University of Alabama School of Law. 


\section{The Clean Water Act’s Approach to Delegated Federalism}

In the fall of 1972, Congress enacted one of the most revolutionary statutes in history - the Clean Water Act. The Act cast aside an earlier program that had relied almost exclusively upon state agencies to adopt and implement water quality standards. In Congress's view, that program had failed due to the reluctance of many states to adopt acceptable standards and appropriate implementation plans. Congress was also exorcised by what some characterized as the near absence of enforcement. So in place of nearly exclusive reliance upon state water standards, Congress adopted a radically new concept and applied it to tens of thousands of water polluters. The new strategy was predicated upon the federal establishment of uniform, technology-based performance limitations. ${ }^{1}$ These limitations, in turn, were to be applied to point source dischargers ${ }^{2}$ through a new permit system which would specifically define the legal obligations of municipal and industrial dischargers. ${ }^{3}$ The state water quality standard program was retained, however, to supplement the technology-based limitations in cases where such a uniform approach was not adequate to meet specific water quality objectives. ${ }^{4}$ Although the newly established U.S. Environmental Protection Agency (EPA) issued many of the initial permits, state agencies could obtain and the vast majority of them have obtained authority to administer the permit program within their borders. ${ }^{5}$ Hence, the Clean Water Act's structure is not just federal, but involves overlapping and intertwined federal and state roles. All fifty states, moreover, enjoy the freedom to establish and enforce regulations that are more protective of the environment than EPA would require.

Although this kind of delegated program federalism is commonly referred to as "cooperative federalism," the fact remains that EPA is the senior partner in most aspects of the relationship. In addition to setting uniform effluent standards, EPA is given veto power over state-issued permits; ${ }^{6}$ the power in extreme instances to withdraw state permitting authority; ${ }^{7}$ the power to review and disapprove state water quality standards; ${ }^{8}$ concurrent enforcement authority; ${ }^{9}$ and the power to shape state programs through the provision of federal financial assistance ${ }^{10}$ and the promulgation of EPA's program

1. $\quad 33$ U.S.C. $\S \S 1311(b)(1)(A),(b)(1)(B),(b)(2), 1316(b)(1)(B)$.

2. The Act defines point sources as "any discernible, confined and discrete conveyance" such as pipes, conduits, ditches, and the like "from which pollutants are or may be discharged." 33 U.S.C. § 1362(14).

3. 33 U.S.C. $§ 1362$ (creating the National Pollutant Discharge Elimination System).

4. $\quad 33$ U.S.C. $§ 1313,1311(\mathrm{~b})(1)(\mathrm{C})$. Of course, the application of water quality driven permit conditions depends upon the existence and subsequent administrative recognition of monitoring data indicating that a particular water is water quality impaired. See generally Oliver A. Houck, The Clean Water Act TMDL Program: Law, Policy, and Implementation 5 (Washington: Environmental Law Institute, $2 d$ ed. 2002) (recounting the paucity of both data and political will).

5. $\quad 33$ U.S.C. $\$ 1362$ (b). Currently, forty-five states possess the authority to issue NPDES permits.

6. $\quad 33$ U.S.C. $\$ 1362(d)$.

7. $\quad 33$ U.S.C. $\$ 1362(\mathrm{c})$.

8. $\quad 33$ U.S.C. $§ 1313(\mathrm{c})(3),(4)$.

9. $\quad 33$ U.S.C $\S 1319$.

$10 . \quad 33$ U.S.C. $\S 1256$. 
regulations. ${ }^{11}$ Congress thus placed primary authority for policy creation and standard setting in the hands of EPA, making the federal government the dominant authority in an area in which state agencies had long held sway. Congress, however, did reserve a significant role for the states and many local governments to play.

In addition to permitting, states establish their own water quality standards; ${ }^{12}$ are responsible for implementing those standards through the establishment of waste load allocations; ${ }^{13}$ are responsible for establishing programs to combat non-point source pollution; ${ }^{14}$ and take the majority of enforcement actions. ${ }^{15}$ Many local governments, furthermore, have a vital role to play in the implementation and enforcement of the pretreatment program, which is designed to regulate industrial discharges to municipallyowned wastewater treatment facilities. ${ }^{16}$ State and local governments may also adopt additional measures that directly or through incentives provide additional protection of their waters. This reservation of authority is found in the Act's approach to federal preemption.

The Clean Water Act only expressly preempts less stringent state and local requirements; not more stringent ones. ${ }^{17}$ Through this kind of floor preemption, Congress expressly gave states and their political subdivisions the latitude to adopt limitations and other requirements that are more stringent than federal limitations and requirements. They can thus be more protective if they wish to be. The Act's floor preemption is endowed with additional punch by virtue of a certification provision that gives states with water quality concerns the power to veto or impose conditions upon a wide variety of federal licensing activities. ${ }^{18}$ Another considerable reservation of state prerogative is found in the Act's savings clause. This provision preserves "any right which any person (or class of persons) may have under any statute or common law to seek enforcement of any effluent standard or limitation or to seek any other relief."19 By virtue of the savings clause citizens can use state common law tort actions to obtain damages for their own injuries while also encouraging, sometimes requiring, dischargers to reduce the kind or amount of pollution they discharge. ${ }^{20}$

\footnotetext{
11. 40 Code of Federal Regulations Part 123 (2006) (setting forth the requirements of state permitting programs under the Clean Water Act).

12. 33 U.S.C. $\S 1313(\mathrm{c})$.

13. 33 U.S.C. $§ 1313(d)$.

14. $\quad 33$ U.S.C. $§ 1329$.

15. William L. Andreen, "Motivating Enforcement: Institutional Culture and the Clean Water Act,"

Pace Environmental Law Review 24, no. 1 (2007): 67, 74-75.

16. $\quad 40$ Code of Federal Regulations Part 403 (2006).

17. $\quad 33$ U.S.C $\S 1370$.

18. $\quad 33$ U.S.C. $\$ 1341$.

19. 33 U.S.C $\$ 1365(\mathrm{e})$.

20. Alexandra B. Klass, "Common Law and Federalism in the Age of the Regulatory State," Iowa Law Review 92, no. 2 (2007): 545. While the Clean Water Act has been held to preempt the federal common law of nuisance (Milwaukee v. Illinois, 451 U.S. 304, 313-15 (1981), litigants may seek relief under the common law of the state where the polluter is located. International Paper Co. v. Ouelette, 479 U.S. 481, 497 (1987).
} 


\section{THE STATES AS LABORATORIES OF DEMOCRACY}

The states, however, infrequently adopt more stringent regulatory standards for water pollution. $^{21}$ In fact, at least twelve states have enacted legislation either forbidding their programs from promulgating standards that are tougher than federal minimum requirements or imposing additional procedures which must be satisfied before such requirements become effective. ${ }^{22}$ Many states have also often been slow to utilize the authority that Congress reserved to them. Most, for example, have been reluctant to establish waste load allocations that are necessary for the implementation of water quality standards. ${ }^{23}$ In addition, many states have chosen non-regulatory and often ineffective approaches for the control of non-point source pollution. ${ }^{24}$ Even state enforcement efforts have been declining for well over a decade. ${ }^{25}$ And instances where states have vetoed or conditioned a federal license on water quality grounds are relatively rare.

One might well conclude that many of these states are engaging, at least in part, in a race to the bottom in order to attract and retain industry through weaker environmental standards, lax implementation, and lethargic enforcement. ${ }^{26}$ Such economic development concerns resonate deeply in many, if not most, state capitals since state politicians generally lack access to any other macroeconomic instruments that can deliver such material benefits to their constituents. ${ }^{27}$ Another significant governor on the vigor of state environmental management efforts may be simple ideological hostility to regulation or the existence of a strong preference for voluntary, private efforts to control water pollution. State environmental agencies, however, may just be reluctant to do battle with entrenched economic interests, interests which in many, if not most, instances wield far more power in state capitals than relatively weak state bureaucracies. ${ }^{28}$

On the other hand, a number of states have taken advantage, at least occasionally, of the power that floor preemption gives them and have forged ahead with innovative

21. Daniel P. Selmi \& Kenneth A. Manaster, 1 State Environmental Law § 11:12 (Eagan, MN: Thomson/West, 2006).

22. Jerome M. Organ, "Limitations on State Agency Authority to Adopt Environmental Standards More Stringent than Federal Standards: Policy Considerations and Interpretive Problems," Maryland Law Review 54, no. 4 (1995): 1373, 1376-86.

23. Houck. The TMDL Program, 63; Linda A. Malone, "The Myths and Truths That Ended the 2000

TMDL Program," Pace Environmental Law Review 20, no. 1 (2002): 63, 78-81.

24. William L. Andreen, "Water Quality Today-Has the Clean Water Act Been a Success?," 55 Alabama. Law Review 55, no. 3 (2004): 537, 545 n.42.

25. Andreen. "Motivating Enforcement," 75. In contrast to the Clean Water Act which empowers private citizens to enforce its requirements, less than half of the state programs do, and of those that do, only one-third allow costs to be shifted in favor of a successful, injured plaintiff. James R. May, "The Availability of State Environmental Citizen Suits," Natural Resources and Environment 18, no. 4 (2004): $53,55-56$.

26. Kirsten Engel, "State Environmental Standard-Setting: Is There a Race and Is It "To the Bottom"?, Hastings Law Journal 48, no. 2 (1997): 271.

27. Timothy Doyle \& Aynsley Kellow, Environmental Politics and Policy-Making in Australia 129 (Melbourne, Australia: Macmillon, 1995).

28. Peter Grobosky \& John Braithwaite, Of Manners Gentle: Enforcement Strategies of Australian Business Regulatory Agencies 207 (Melbourne, Australia: Oxford University Press, 1986) (finding a more cooperative regulatory approach among agencies that deal with smaller numbers of regulated entities). 
approaches to some environmental problems. The most notable recent example of this type of state action involves climate change. Due to the reluctance of the federal government to regulate greenhouse gases such as carbon dioxide, about one-third of the states have enacted new legislation or implemented executive orders designed to reduce the generation of greenhouse gases within their borders. ${ }^{29}$ With regard to water pollution, perhaps the most obvious examples of more protective state action are found in a number in water quality certification cases. In PUD No. 1 of Jefferson County $v$. Washington Department of Ecology, the Supreme Court upheld the state of Washington's imposition of a minimum stream flow requirement as a condition precedent to the issuance of a federal license for the construction of a new hydroelectric dam. ${ }^{30}$ More recently, the Supreme Court upheld a state certification not only stipulating minimum stream flow, but also passage for migratory fish and eels, for the federal re-licensing of five hydroelectric dams on Maine's Presumpscot River. ${ }^{31}$ In the aftermath of another Supreme Court case, this one reducing the jurisdictional scope of the Clean Water Act, ${ }^{32}$ a number of states took some action to ameliorate the resulting jurisdiction void. ${ }^{33}$

So the states can serve and many have served, from time to time, as "laboratories of democracy." 34 In doing so, these states have filled various regulatory gaps left by the federal government. They have also, through their trial-and-error experimentation with new approaches, created models worthy of emulation by other jurisdictions. Congress, in fact, based the citizen suit provision found in the 1970 Clean Air Act upon an earlier Michigan statute, and the concept of using water pollution permits in the Clean Water Act had its origin in the systems created by a number of states. Of course, state establishment of more stringent requirements often provokes a backlash among the economic and industrial powers whose interests have been adversely affected. Thus, the victory which the state of Washington enjoyed in setting minimum flow conditions in PUD No. 1 led the Republican dominated House of Representatives in 1995 to pass a bill that would have deprived states of this authority. ${ }^{35}$ Indeed, many of the chapters in this book discuss recent legislative and regulatory actions that attempt to impose federal limits or ceilings upon state action.

29. Kirsten H. Engel \& Scott R. Saleska, "Subglobal Regulation of the Global Commons: The Case of Climate Change," Ecology Law Quarterly 32, no. 2 (2005): 183, 185; Barry G. Rabe, et al, "State

Competition as a Source Driving Climate Change Mitigation, New York University Environmental Law Journal 14, no. 1 (2005): 1, 8-11.

30. $\quad 511$ U.S. 700, 709-10 (1994).

31. S.D. Warren Co. v. Maine Board of Environmental Protection, 126 S.Ct. 1843, 1847 (2006).

32. Solid Waste Agency of Northern Cook County v. Army Corps of Engineers, 531 U.S. 159, 171

(2001).

33. Michael J. Gerhardt, "The Curious Flight of the Migratory Bird Rule," Environmental Law Reporter 31, no. 9 (2001): 11,079, 11,085.

34. New State Ice Co. v. Liebmann, 285 U.S. 262, 311 (1932) (Justice Brandeis, dissenting).

35. "State Authority to Ensure Water Quality under Attack," American Rivers 23, no. 2 (1995) 5. 


\section{DEVOLUTiOn?}

The debate about the appropriate approach to federalism in water pollution control, however, does not only involve the question of precluding more protective action by state government and state courts. The most common debate about the appropriate distribution of power between the states and the federal government in this policy arena has focused upon whether the federal government should have a primary role to play, aside perhaps from the provision of financial and technical assistance to the states and dealing with the spill-over effects of interstate pollution. Richard Revesz, for instance, has argued that federal environmental statutes which set regulatory floors hobble state efforts to craft regulatory regimes that meet their own conceptions of the public good. ${ }^{36}$ Thus, if they are constrained from competing over environmental regulation because it has been nationalized in part, they will be forced to compete in other ways such as by offering lax standards in other regulatory areas or by providing various financial incentives to industry. ${ }^{37}$ In a different vein, Jonathan Adler has contended that a reduced federal presence could enhance the effectiveness of environmental regulation by increasing the need for innovative state reforms. ${ }^{38}$ More specifically, Adler has suggested that federal regulatory floors can actually discourage more stringent or wiser state action by either signaling that state action is unnecessary or by "crowding out" the need for state action. ${ }^{39}$

Those who favor a more decentralized approach to environmental regulation - a devolution of authority from the federal to the state level — often point to commentators who claim that the states were actually making significant environmental progress prior to the 1970s and the enactment of the modern federal pollution control statutes. Although most of these commentators focus on our nation's experience with two air pollutants, particulate matter and sulfur dioxide, ${ }^{40}$ one of these commentators looked at water pollution. After examining reports discussing EPA's first national water quality inventory which was issued in 1974, A. Myrick Freeman concluded that "there had been significant improvements in most major waterways" during the 1960s "at least in regard to organic wastes and bacteria." 41 Adler, in turn, based on Freeman's work, has argued that this evidence "suggests that states began addressing those water quality problems

36. Richard L. Revesz, "Rehabilitating Interstate Competition: Rethinking the 'Race to the Bottom' Rationale for Federal Environmental Regulation,” New York University Law Review, 67, no. 6 (1992):

1210.

37. Richard L. Revesz, "The Race to the Bottom and Federal Environmental Regulation: A Response to Critics," Minnesota Law Review 82, no. 2 (1997): 535, 541.

38. Jonathan H. Adler, "Judicial Federalism and the Future of Federal Environmental Regulation," Iowa Law Review 90, no. 2 (2005): 377, 464.

39. Jonathan H. Adler, "When Is Two a Crowd? The Impact of Federal Action on State

Environmental Regulation," Harvard Environmental Law Review 31, no. 1 (2007): 67, 94-99.

40. Indur Goklany, Clearing the Air: The Real Story of the War on Air Pollution (Washington: Cato Institute, 1999), 49-56; Paul R. Portnoy, Air Pollution Policy, in Public Policies for Environmental Protection, Paul R. Portney \& Robert N. Stavins, eds. (Washington: Resources for the Future, 2000), 77; Robert W. Crandall, Controlling Industrial Pollution: The Economics and Politics of Clean Air (Washington: Brookings Institution, 1983), 19.

41. A. Myrick Freeman, Water Pollution Policy, in Public Policies for Environmental Protection, Paul R. Portnoy \& Robert N. Stavins, eds. (Washington: Resources for the Future, 2000), 187. 
that were clearly identified and understood well before the federal government." 42 History, therefore, demonstrates the "environmental benefits of decentralization," and provides "ample reason to question the assumption that lessening federal environmental regulatory authority necessarily results in lessened environmental protection."43 Hence, our present reliance upon delegated federalism is unnecessary and federal power can be curtailed without producing negative environmental ramifications.

Such claims must be closely scrutinized against the historical record for any substantial change in our current regulatory paradigm could seriously undermine the effectiveness of our national effort to obtain and maintain clean and healthy waters. The question is not whether we are going to permit state experimentation or not. State experimentation is clearly available under the current approach to preemption, an approach which permits states to innovate and institute new policies as long as they do not fall below minimum environmental standards. The question, rather, is whether we are willing to remove that floor, that safety net, and permit states to pursue policy initiatives which fall below those minimum requirements.

A careful examination of the 1974 EPA report, ${ }^{44}$ reveals no historical support for the broad contentions that have been based upon it. While it does conclude that some improvement had occurred with respect to a few water pollutants, the report cannot be considered a comprehensive assessment of progress in the fight against water pollution. The report is flawed in many ways, reflecting, no doubt, the complexity of attempting to detect trends in water quality. The EPA, for example, did not attempt to control for variations in stream flow, a factor that strongly affects concentrations of organic pollutants due to the impact of dilution. The monitoring stations from which the data was drawn, moreover, were not held uniformly constant - thereby injecting a degree of ambiguity into many of the report's conclusions. In short, EPA's report is not good evidence that water pollution was improving nationwide during the ten years prior to the enactment of the Clean Water Act, and it lends no support to the claim that federal authority can be reduced today without incurring adverse environmental impact.

Water quality, however, was improving in some locations in the years leading up to 1972. This progress was largely the result of the construction and upgrading of a number of municipal wastewater treatment facilities. These local improvements, however, were not exclusively the product of state and local action since the federal government was also active in some water pollution control activities in the 1960s and early 1970s. During those years, the federal program was providing funding, albeit at inadequate levels, for the construction of municipal sewage treatment plants; was pushing state agencies to adopt water quality standards, anti-degradation policies, and adequate implementation plans; and was involved in a number of enforcement actions. ${ }^{45}$

\footnotetext{
42. Adler, "Judicial Federalism," 465.

43. Ibid., 464-65.

44. U.S. Environmental Protection Agency, "National Water Quality Inventory" (1974).

45. William L. Andreen, "The Evolution of Water Pollution Control in the United States - State, Local, and Federal Efforts, 1789-1972: Part II", Stanford Environmental Law Journal 22, no. 2 (2003): $215,239-42 ; 249,252-55$.
} 
Nevertheless, the best data we have indicates that the overall quality of the nation's waters was not improving at this time; in fact, the situation appears to have been growing worse. Not only had the earlier federal program had been inadequate to the task, but so had been state efforts. It was time, therefore, to institute a wholly new approach, an approach which has produced remarkable progress over the past 35 years.

\section{A Closer LOOK AT THE 1974 EPA REPORT}

The Clean Water Act requires each state to prepare a biennial report on the condition of its water quality and its progress towards achieving the Act's goal of fishable and swimmable waters. EPA, in turn, must transmit these reports to Congress along with the agency's analysis of the state results. ${ }^{46}$ EPA's 1974 section 305(b) report, however, could not rely upon state submitted data since the states had not had time in the short period following the passage of the Act to collect the stream quality and effluent data upon which their reports would depend. EPA, therefore, prepared the 1974 report using its STORET (storage and retrieval) database to try to analyze national trends in water quality during the previous decade. ${ }^{47}$ In doing so, EPA relied upon data from 1,300 monitoring stations located along 22 waterways in an effort to discern what if any changes in water quality had occurred between the period of 1963-67 and that of 1968$72 .{ }^{48}$ Since many of these stations did not collect data throughout the duration of the study period, EPA often substituted data from stations located elsewhere along that particular waterway, ${ }^{49}$ adding a variability that substantially lessens the confidence which one might otherwise have in the trends the report claims to have detected. ${ }^{50}$

According to the report, there had been "general improvements" in organic pollution, bacteria, ammonia, and suspended solids. ${ }^{51}$ Organic pollution, commonly measured as biological oxygen demand (BOD) had apparently improved in 74 percent of the river segments that were analyzed, producing improved dissolved oxygen (DO) levels on 61 percent; bacteria levels had improved on 58 to 78 percent; ammonia on 76 percent; and suspended solids on 82 percent. Nevertheless, EPA noted that bacteria levels and suspended solids remained at persistently high levels. In addition, EPA reported significantly worsening trends for two nutrients - nitrogen and phosphorus. Concentrations of total phosphorus had apparently increased in 82 percent of the river segments and nitrates in 74-76 percent. ${ }^{52}$ Overall, EPA concluded that more stream segments had become moderately polluted during the decade, although fewer were

\footnotetext{
46. $\quad 33$ U.S.C. $\S 1315(b)$.

47. U.S. Environmental Protection Agency, "National Water Quality Inventory 1974," 1, 9. EPA's STORET database, first developed in 1964, is one of the most venerable environmental database systems still in use. Maintained by the agency's Office of Wetlands, Oceans, and Watersheds, STORET contains data from ambient water quality monitoring stations, from effluent monitoring, and from intensive surveys. U.S. Environmental Protection Agency, "National Water Quality Inventory 1996," 381.

48. U.S. Environmental Protection Agency, "National Water Quality Inventory" (1974), 13.

49. Ibid., 13, 72, 110, 133.

50. Ibid., 110.

51. Ibid., 22.

52. Ibid.
} 
heavily polluted. But the vast majority of the 36 river segments that were assessed appear to have been in violation of EPA water quality guidelines for at least one pollution parameter in the period of 1968-72 and over 60 percent were in violation of eight or more parameters. $^{53}$

The limitations of the report were recognized at the time. The Council on Environmental Quality (CEQ) urged that the report "should be interpreted with caution" since, among things, DO concentrations fluctuate with stream flow and temperature. ${ }^{54}$ The concerns expressed by CEQ were well-founded. The Northeast, Middle Atlantic, Midwest, and Central states had all experienced widespread drought conditions from 1963 to $1966,{ }^{55}$ thus overlapping with three of the four years in EPA's initial snapshot of the nation's water quality. Low precipitation produces lower flow conditions, and lower flows produce the highest concentration of organic pollution and thus the lowest levels of DO ${ }^{56}$ By contrast, the years between 1968 and 1972 were not years characterized by widespread drought, ${ }^{57}$ and hence one would expect lower concentrations of organic pollution and higher levels of DO.

Since a major variable was not held constant, it would stretch credibility to conclude that levels of organic pollution in the nation had actually improved over the course of the 1960s. In fact, a recent EPA study indicates that the effluent loading of organic pollutants from municipal wastewater treatment facilities had actually increased 8 percent between 1962 and 1972. ${ }^{58}$ Therefore, what EPA may have been comparing, at least to some extent, was the impact of dilution upon discharges of municipal waste, which typically contain organic material, bacteria, and ammonia. ${ }^{59}$ That would explain much of the observed "improvement" in those parameters. The impact of increased dilution would also have minimized the contribution of organic discharges from industry, which, as the next section explains, were nearly equal to the contribution from the municipal sector.

53. Ibid., 24-25. It would be impossible to accurately compare the waters violating EPA guidelines in 1974 with those that are classified as violating the guidelines in later years since many of the reference points have been strengthened to better protect human health and the environment. In 1974, for example, EPA used a reference point of $4.0 \mathrm{mg} / \mathrm{l}$ for dissolved oxygen (for fish and wildlife) and 2,000 fecal coliforms per $100 \mathrm{ml}$ (for recreation). U.S. Environmental Protection Agency, "National Water Quality Inventory" (1974), 24-25. In 1976, those criteria were strengthened to $5.0 \mathrm{mg} / 1$ and 200 fecal coliforms per 100 ml, respectively. U.S. Environmental Protection Agency, "Quality Criteria for Water," 42, 123 (1976). Subsequent revisions are found in U.S. Environmental Protection Agency, "Quality Criteria for Water" 4250, 209-19 (1986).

54. Council on Environmental Quality, "Fifth Annual Report" (1974), 287.

55. Andrew Stoddard, et al., Municipal Wastewater Treatment: Evaluating Improvements in National Water Quality (New York: John Wiley \& Sons, 2002), 111; U.S. Environmental Protection Agency, "National Water Quality Inventory" (1974), 104 (acknowledging that the period 1968-72 was much wetter than 1963-67 in the Ohio River watershed).

56. Stoddard, National Water Quality, 108-11.

57. Ibid., 554-58.

58. Ibid., 477.

59. One would, of course, expect run-off related pollutants, such as bacteria from animal feeding operations to increase during periods of high precipitation. Such increases in rural areas, however, may not have offset the broad-scale dilutional impact that increased flows had on bacteria discharged by urban sewerage systems. 
The improvement in suspended solids, however, cannot be attributed to higher stream flows since one would expect sediment and silt to rise with higher flows due to greater run-off and the scouring of stream bottoms. Rivers are simply more turbid, as a general matter, during high flows than during low flows. Thus EPA's report suggests a striking improvement in concentrations of suspended solids. EPA attributed the improvement to many factors. In its detailed discussion of the Ohio River, for instance, EPA stated that the downward trend along the river may have been due to the fact that the same monitoring stations were not being relied upon during both periods of time. In fact, at stations that were measured during both time periods, levels of suspended solids were actually increasing. ${ }^{60}$ The introduction of new high-head dams may also account for part of the observed improvement, ${ }^{61}$ and higher flows and increased velocity may actually improve turbidity levels in some rivers. ${ }^{62}$ At any rate, the overwhelming majority of suspended solids in our nation's waters result from non-point source discharges erosion from agricultural fields, construction sites, mining operations and logging activities, as well as urban run-off - discharges that went virtually unregulated during those years. So, if there was any improvement with regard to suspended solids, it is unlikely that much of it was the result of state regulatory action.

On the other hand, the more widespread use of wastewater treatment technology (especially primary treatment where solids are removed from raw sewage) by the nation's cities and towns did produce lower discharges of suspended solids from that point source category. In fact, EPA has recently concluded that discharges of suspended solids from publicly-owned sewage treatment plants decreased 9 percent between 1962 and $1972 .{ }^{63}$ This decrease, however, was likely undetectable since it would have been dwarfed by the combined level of suspended solids from industry ${ }^{64}$ and non-point sources.

\section{An Evaluation of Progress in the Decade Prior to Enactment of the Clean WATER ACT}

Although EPA's 1974 report does not appear to be a reliable barometer of an improving trend in national water quality, there is no doubt that some progress was being made in the years before the Clean Water Act was passed. That progress - generally limited to specific streams in particular states or regions - was primarily, but not exclusively, the result of state and local action.

The state of Oregon, for instance, made great strides in cleaning up the Willamette River, a river which had been known as the filthiest stream in the Northwest. As the result of state action, all of the municipalities discharging to the river implemented

60. U.S. Environmental Protection Agency, "National Water Quality Inventory” (1974), 110.

61. Ibid. (referring to new dams along the Ohio).

62. Ibid., 72 (referring to the lower Mississippi River).

63. Stoddard, National Water Quality, 481.

64. Discharges of suspended solids from industry in 1973 amounted to approximately 898,010 metric tons per day compared to 7,531 metric tons per day from municipal wastewater treatment plants. Ibid., 589 . 
primary treatment, which removes about 30 percent of organic waste, between 1949 and 1957. In 1960, the state increased the requirement for these municipal facilities to secondary treatment, which removes approximately 85 percent of organic waste, and, in 1967, it extended the secondary treatment requirement to industrial dischargers. As a result, by 1972 BOD discharges by point sources to the river had dropped 75 percent from 1957 levels. ${ }^{65}$ Nevertheless, bacteria counts still violated standards more often than not and toxic discharges from the paper and pulp industry remained high in the lower 80 miles of the river. ${ }^{66}$

Although the Twin Cities of Minneapolis and St. Paul constructed a primary treatment facility in 1938, increased discharges associated with population growth had overwhelmed the assimilative capacity of the Mississippi River by the 1960s. According to the Federal Water Pollution Control Administration which studied this section of the Mississippi in 1964, the river bottom for twenty miles was "thick with sewage sludge," and devoid of the organisms associated with a healthy stream. ${ }^{67}$ Not surprisingly, the water was low in dissolved oxygen and high in bacteria. The bleak situation prompted local officials to upgrade the Twin Cities facilities to secondary treatment in 1966, an action which immediately improved water quality below the plant. On the other hand, 88 percent of the suburban sewage treatment plants in the Twin Cities metropolitan area persisted in discharging inadequately treated waste to the Mississippi River, ${ }^{68}$ Bacteria counts remained high, and dissolved oxygen occasionally fell to extremely low levels. ${ }^{69}$

Along the Delaware River, most municipal sewage plants above Philadelphia had installed secondary treatment by 1960. Below Philadelphia, however, dissolved oxygen levels remained abysmally low. ${ }^{70}$ In Chattanooga, improvements to the sewage treatment plant rendered the Tennessee River suitable for recreation downriver, except for areas immediately downstream of the plant itself and along the city's waterfront. ${ }^{71}$ Many other waterways, such as the James River, the Potomac River, the Connecticut River, and large stretches of the Chattahoochee River, remained grossly polluted. ${ }^{72}$ The progress $^{2}$ that had been made was, unfortunately, neither national in scale nor comprehensive in nature.

65. Ibid., 405-06. In response to the federal Water Quality Act of 1965, Oregon established intrastate and interstate water quality standards in 1967, standards which were among the first of the new state standards to be approved by the federal government. Ibid., 405 . The federal government also provided millions of dollars for the construction and upgrading of municipal wastewater facilities along the Willamette between 1956 and 1972. Ibid.

66. U.S. Environmental Protection Agency, "National Water Quality Inventory" (1974), 235.

67. Stoddard, National Water Quality, 369.

68. Ibid., 368-69.

69. U.S. Environmental Protection Agency, "National Water Quality Inventory" (1974), 73, 76.

70. Stoddard, National Water Quality, 262.

71. U.S. Environmental Protection Agency, "National Water Quality Inventory" (1974), 140. The Tennessee River had been the focus of some federal enforcement attention during the 1960s and had been listed as the subject of a potential enforcement conference as early as 1963. Stoddard, National Water Quality, 419.

72. Ibid., 204-05, 285, 316, 334. 
Much of the progress that was made, moreover, was due to federal efforts. Of the nearly $\$ 5.3$ billion that was spent on the construction of sewage treatment facilities during the $1960 \mathrm{~s}, \$ 1.1$ billion came from the federal government. ${ }^{73}$ Although the federal contribution may have amounted to only a quarter of the total amount spent, the existence of this federal grant program created an incentive that often prompted state and local governments to invest in their infrastructure. ${ }^{74}$ As a result of these state, local, and federal efforts, the number of municipal treatment facilities providing secondary treatment rose from 6,719 in 1962 to 13,893 in $1972 .^{75}$ Unfortunately, the number of sewer systems providing no treatment remained stationary — rising marginally from 2,262 to 2,265 - while the number of systems providing only primary treatment fell slightly from 2,717 to $2,530 .^{76}$ So, despite the expansion of efforts during the 1960 s to build modern treatment facilities for municipal waste, the amount of sewage discharged with inadequate treatment (less than secondary) remained essentially unchanged at 9,375 million gallons a day (MGD) in 1972 compared with 9,372 MGD in 1962 - although the amount discharged without any treatment did fall by 1,594 MGD. In terms of organic material discharged from these facilities, the nation was losing ground. The discharge of organic pollutants from the nation's sewer systems grew from 11,765 metric tons per day in 1962 to 12,558 metric tons per day in 1972. ${ }^{77}$ That rise might account, at least in part, for the results of a CEQ contracted study which found that oxygen-demanding water pollution had grown, primarily in urban areas, between 1965 and $1970 .^{78}$

Much of the responsibility for that apparent growth, however, must be borne by industry as well. In 1973, industry was responsible for approximately 43 percent of the sewered oxygen demand in U.S. waters. ${ }^{79}$ Industry's overall contribution to the pollution

73. U.S. Environmental Protection Agency, "The Cost of Clean Water, Volume II: Cost Effectiveness and Clean Water" (1971), 19. Federal expenditures on the construction grants program would have been nearly twice as large in the 1960s, but the program's funding fell victim to cost of fighting the Vietnam War. Andreen, "Evolution of Water Pollution Control: Part II," 252 (relating that $\$ 750$ million of the sums authorized for expenditure in 1968 and 1969 were never appropriated).

74. According to the Associate Director of the U.S. Conference of Mayors, approximately half of the money that state and local government contributed to this effort was stimulated by the availability of federal grant money. Water Pollution Control: Hearings Before a Special Subcommittee of the Senate Committee on Public Works, $88^{\text {th }}$ Cong. 93 (1963) (testimony of Hugh Mield, Jr.). In addition, some state and local actions were no doubt spurred by the publicity generated and recommendations issued by some 51 federal enforcement conferences which were convened between 1957 and 1970. Water Pollution Control Legislation, 1971: Hearings Before the House Committee on Public Works, 92d Cong. 179 (1971) (statement of John Quarles, General Counsel of EPA, recounting the spotlight which the conferences shined upon persistent water pollution problems).

75. Stoddard, National Water Quality, 458.

76. Ibid.

77. Ibid., 469. Since the influent of organic material had grown during the decade, the overall removal efficiency, however, had improved from 38.3 percent to 45 percent. Ibid., 470.

78. Council on Environmental Quality, "Third Annual Report" (1972), 13. The study, performed by Enviro Control, Inc., made some corrections to account for flow variations. However, due to a limited number of monitoring locations from which the data was drawn, the study did "not represent a complete and properly weighted cross section of all U.S. waters." Ibid.

79. Stoddard, National Water Quality, 588. A much earlier EPA study, however, estimated that industry was responsible for nearly 80 percent of sewered oxygen demand in 1968. U.S. Environmental Protection Agency, "The Cost of Clean Water, Volume II: Cost Effectiveness and Clean Water" (1971), 64. 
of the nation's waterways, moreover, was staggering - representing roughly 63 percent of all wastewater discharged by point sources into waters of the United States. ${ }^{80}$ As late as 1968 , some 70 percent of the annual industrial discharge of over 14 trillion gallons of wastewater received absolutely no treatment whatsoever, ${ }^{81}$ and much of the rest enjoyed only rudimentary treatment. ${ }^{82}$ The amount of untreated industrial effluent, moreover, increased at an annual rate of 1.6 percent between 1964 and $1968,{ }^{83}$ while the overall percentage of industrial waste treated to one extent or another improved only modestly from 29.2 percent to 30.4 percent. $^{84}$

The nation, in short, appears to have been losing ground in its struggle with water pollution. The amount of industrial waste which received treatment remained ridiculously low, and the amount of untreated industrial effluent was growing. Meanwhile, the amount of organic waste being discharged from municipal facilities was still rising. In 1969, 41 million fish were killed by water pollution, the highest number of fish deaths reported since an annual census had begun in $1960,{ }^{85}$ but a record broken in 1971 when nearly 74 million fish were killed in U.S. waters. ${ }^{86}$ Other examples of foulsmelling, repulsive water conditions appeared year after year. ${ }^{87}$ It was no surprise in 1971, therefore, when the federal government announced that a substantial portion of U.S. waters were "persistently polluted" 88 - waters, in other words, that consistently violated established water quality criteria. ${ }^{89}$

80. In 1968, municipal sewer systems discharged 23,116 million gallons of wastewater per day (Stoddard, National Water Quality, 460) or 8,437 billion gallons per year. By contrast, a total of 14,276 billion gallons of wastewater were discharged in 1968 by large manufacturing facilities — defined as those facilities using over 20 million gallons of water per day. U.S. Environmental Protection Agency, "The Economics of Clean Water, Volume I" (1972), 20. This comparison, therefore, is a rough one, not only because small, medium, and fairly large manufacturing plants were not included in the industrial discharge statistic, but because approximately 7 percent of the waste that was disposed of by the surveyed "large" industrial facilities was discharged to municipal sewer systems. Ibid., 17.

81. Ibid., 25, 28.

82. William H. Rodgers, Jr., "Industrial Water Pollution and the Refuse Act: A Second Chance for Water Quality," 119 University of Pennsylvania Law Review 119, no. 5 (1971): 761, 764. According to EPA, the absence of data at this time made it impossible to estimate "the degree of treatment received by final industrial waste discharge." U.S. Environmental Protection Agency, "The Economics of Clean Water, Volume I" (1972), 28.

83. Ibid., 28.

84. Ibid., 26.

85 Federal Water Quality Administration, “1969 Fish Kills” (1969), 1.

86. U.S. Environmental Protection Agency, "Fish Kills Caused by Pollution: Fifteen-Year Summary 1961-1975" (1975), 5.

87. William L. Andreen, "The Evolution of Water Pollution Control in the United States-State, Local, and Federal Efforts, 1989-1972: Part I," Stanford Environmental Law Journal 22, no. 1 (2003): 145, 197-98.

88. U.S. Environmental Protection Agency, "The Cost of Clean Water, Volume II: Cost Effectiveness and Clean Water" (1971), 52.

89. Ibid., 55. 


\section{THE IMPACT OF THE CleAN WATER ACT UPON WATER QUALITY}

In contrast to the stubbornly degraded conditions that dominated water quality in the 1960s, the Clean Water Act has produced real, substantial progress. An EPA-funded study that was conducted in the late 1990s found that municipal wastewater treatment plants discharged 23 percent less organic waste in 1996 than in 1968, despite the fact that loadings of BOD (influent) had increased by 35 percent over the same period. ${ }^{90}$ Over a shorter period of time (1973 to 1995), the amount of BOD discharged by industry fell by 40 percent. $^{91}$ Even though a substantial portion of the decline in industrial BOD discharges can be linked to the fact that many industrial facilities shifted their discharges to municipal systems, the overall decline in BOD discharges is significant, and can be attributed to the construction and renovation of thousands of municipal treatment facilities, ${ }^{92}$ as well as to the imposition and enforcement of technology-based effluent limitations. ${ }^{93}$

The most innovative aspect of this particular study, however, was its approach to assessing nationwide trends in ambient dissolved oxygen concentrations brought about by regulating point source discharges of BOD. The study examined DO levels both before and after the passage of the Clean Water Act and evaluated changes in DO only for monitoring stations that were impacted by point sources; stations influenced solely by non-point sources were excluded. ${ }^{94}$ In an effort to isolate low flow conditions (thus screening out the noise produced by seasonal variations in precipitation, flow and temperature, and minimizing the impact of non-point source loadings), ${ }^{95}$ the monitoring data was limited to the months of July through September, and to represent comparable worst-case, low flow conditions, two especially dry periods were chosen: 1961-1965 (before passage) and 1986-1990 (after passage). ${ }^{96}$ The study was also intended to go beyond prior inquiries and determine whether point source controls had only produced only localized effects, as some previous reports had noted, ${ }^{97}$ or had actually produced broader stream improvement. ${ }^{98}$ The study, therefore, evaluated changes at three different scales: river reaches (small scale); catalog units (medium scale); and major river basins (large scale). ${ }^{99}$

90. Stoddard, National Water Quality, 61 (measuring ultimate BOD of the carbonaceous and nitrogenous components of oxygen consumption).

91. In 1973, industrial discharges of BOD amounted to 5,406 metric tons per day compared to 3,243 in 1995. Ibid., 588, 590 .

92. Between 1970 and 1999 , the federal government provided $\$ 77.2$ billion for the construction of publicly owned treatment works, a sum which was combined with state and local expenditures of roughly the same magnitude. Andreen, "Evolution of Water Pollution Control, Part II," 552.

93. Stoddard, National Water Quality, 5-6.

94. Ibid., 122.

95. Ibid., 120.

96. Ibid., 107-21.

97. Debra S. Knopman \& Richard A. Smith, "20 Years of the Clean Water Act," Environment 35, no. 1 (1993): 16, 34-35.

98. Stoddard, National Water Quality, at 105.

99. Ibid., 7-10. 
Perhaps surprisingly, the investigators documented "significant improvements" in summer DO conditions at all three spatial scales. ${ }^{100}$ In fact, they found progress in over two-thirds of the reaches, catalog units, and major river basins which they surveyed.

Sixty-nine percent of the river reaches that were assessed (representing largely urbanized, industrial areas) experienced improved levels of DO. The reaches with the greatest increases saw improvements ranging from 4.1 to $7.2 \mathrm{mg} / \mathrm{L}$, and the percentage of reaches having worst-case, low-flow DO levels above the benchmark of $5.0 \mathrm{mg} / \mathrm{L}^{101}$ rose from 46 percent to 69 percent. In addition, 68 percent of the larger catalog units (again dominated by urban/industrial areas) enjoyed higher levels of DO. As with the smaller scale reaches, the percentage of catalog units with worst-case DO levels meeting or exceeding $5.0 \mathrm{mg} / \mathrm{L}$ also rose, this time from 53 percent to 74 percent. $^{102}$ Finally, eight of the eleven major river basins that were examined enjoyed "statistically significant improvement," while the other three basins did not suffer significant degradation. ${ }^{103}$ According to the investigators, "Given the very large spatial scale of the major river basins, it is remarkable to observe statistically significant before and after DO improvements as detected using the systematic methodology [which we employed]." ${ }^{\prime 104}$

Many water quality problems remain, especially those linked to non-point source discharges, contaminated sediments, sewer overflows, hydrologic modifications, and habitat degradation. ${ }^{105}$ The evidence, however, is unambiguous; the initial regulatory strategy contained in the Clean Water Act has been successful. The application of technology-based limitations through the NPDES permit system which allows for state participation, enforcement, and amplification, while not perfect, has largely lived up to its pre-enactment billing. Together with the expenditure of some $\$ 150$ billion on municipal wastewater treatment facilities, this classic form of command-and-control regulation within the structure of delegated federalism has produced astonishing improvements in water quality. The continuation of this success, however, is by no means assured. One of the oldest approaches to pollution control, state water quality standards, still awaits full implementation. Indeed, it is ironic that so many states, having expressed a strong preference for water quality standards over technology-based limitations when the Clean Water Act was written, have proven so reluctant to impose water quality derived restrictions upon both point sources and non-point sources. ${ }^{106}$ Another great challenge, albeit one that receives much less attention, is the future federal funding of municipal wastewater treatment facilities. Our growing population and aging infrastructure will likely reverse much of the progress we have made since the early 1970s unless many

100. Ibid., xvi.

101. Five $\mathrm{mg} / \mathrm{l}$ is considered to be the dividing line between healthy and unhealthy levels of DO. Ibid., 6. However, the actual water quality standards in a number of southern states permit DO excursions down to $4.0 \mathrm{mg} / \mathrm{l}$ during specifically-defined low flow conditions.

102. Ibid., 175.

103. Ibid., 176.

104. Ibid.

105. Andreen, "Water Quality Today," 542-46, 564, 578-91.

106. Houck, The TMDL Program, 5, 63; Linda A. Malone, "The Myths and Truths That Ended the 2000 TMDL Program,” Pace Environmental Law Review 20, no.1 (2002): 63, 78-81. 
existing plants are upgraded and new, more sophisticated facilities constructed. ${ }^{107}$ A new and significantly enhanced federal commitment must be made and sustained, or many of | our gains will be lost. ${ }^{108}$

\section{CONCLUSION}

Despite the efforts of state and local government, the fight against water pollution at the end of the 1960s was foundering. Insufficient resources had been committed to the construction of municipal wastewater treatment facilities, while the regulation of industry was in most cases non-existent. Seventy percent of all industrial wastewater, in fact, still received no treatment. State water quality standards were often weak, and so were state enforcement programs. ${ }^{109}$ Even if the will to enforce were present, the general lack of monitoring data made proving or even learning of a water quality violation difficult, and the nearly uniform lack of discharge-specific limitations made linking a violation to a specific polluter nearly impossible in many cases. ${ }^{110}$ The result was pervasive pollution and hundreds of impaired waters. One should, therefore, be wary of broad claims that state and local water pollution programs "were making environmental progress" in the 1960s. ${ }^{111}$ While some programs were producing progress, the overall picture was dismal. "In the face of a growing population and rapidly expanding manufacturing activity, state regulatory efforts were proving too little, too late."112

That lack of general success cannot be ascribed entirely to state and local government. The federal government had been active in some aspects of water pollution control for decades, and the pace of its involvement was accelerating during the 1960s with an expanded construction grants program, a new water quality standards program, and the use of section 13 of the Rivers and Harbors Act as a device in the struggle against water pollution. ${ }^{113}$ This expanded federal program, however, was clearly not equal to the task. So, despite some increasing effort at the state, local, and federal levels and some success stories, the overall trend at the advent of the 1970s was not encouraging. Relying upon more of the same in the hope that state efforts "would pick up steam in the years to come" 114 was a course that Congress, clearly annoyed with the growing degradation of our waters, rejected in 1972 .

Congress, therefore, charted a completely new regulatory course with the enactment of the Clean Water Act. The navigation of that new course has not been easy, and there have been and continue to be numerous pitfalls. However, the application of

\footnotetext{
107. Stoddard, National Water Quality, 99.

108. U.S. Environmental Protection Agency, "The Clean Water and Drinking Water Infrastructure Gap Analysis (2002), 6, 14-15.

109. Andreen, "Evolution of Water Pollution Control, Part II," 252-55.

110. Houck, Clean Water Act TMDL Program, 3 n.3.

111. Jonathan H. Adler, "Fables of the Cuyahoga: Reconstructing a History of Environmental

Protection," Fordham Environmental Law Journal 14, no. 1 (2002): 89, 138.

112 Andreen, "Evolution of Water Pollution Control, Part I," 196-97.

113. Rodgers, "Industrial Water Pollution and the Refuse Act," 761.

114. Adler, "Fables of the Cuyahoga," 138.
} 
federal technology-based effluent limitations through the NPDES permit system has proven to have been a wise, initial course of action. Together with an expanded construction grants program, the technology-based approach has produced tremendous reductions in the level of both industrial and municipal point source pollution. More, much more remains to be done. But, we should recognize success, even partial success, when it occurs. And the credit for this success must be shared broadly.

It, nevertheless, must be recognized that the effort prior to 1972 was primarily a state effort, as it had been for decades. The overall failure of that approach stands in stark contrast to the success which we have witnessed under the Clean Water Act. Those results ought not to be forgotten whenever there are calls to de-construct the Clean Water Act by stripping EPA of the authority to set and oversee the achievement of basic regulatory requirements. Such calls, which run counter to the lessons of history, need to be carefully and critically evaluated.

Part of the genius of the Clean Water Act, however, lies in its grant of authority to the states and state common law litigants to go further and seek protections that lie beyond the minimum requirements of federal law. Thus, the Clean Water Act permits states and state courts to pitch in and fill regulatory voids wherever the Act fails to address modern environmental concerns or whenever EPA fails to adequately implement or enforce existing law. Such gap filling actions, unfortunately, are not common enough. In fact, it seems as if many states would prefer not to vigorously enforce or implement even the basic requirements of the Clean Water Act. It is fortunate, therefore, that the basic federal floor requirements remain as part of a regulatory structure which has, despite its flaws and occasional poor leadership, served the nation well since 1972. 


\title{
12 Delegated Federalism Versus Devolution: Some Insights from the History of Water Pollution Control
}

\author{
William L. Andreen
}

This chapter examines the claim that state and local governments were beginning, prior to the enactment of the Clean Water Act in 1972, to make significant progress in the fight against water pollution. Based on this premise, some have argued that there is good reason to be skeptical about the necessity for continued federal involvement in water pollution control. At their broadest, such scholars use this revisionist history to question other federal environmental statutes' structures as well. The implication of this argument is that the devolution of regulatory authority to the states would not produce lower levels of environmental protection. Thus our present approach to water pollution control delegated program federalism, a form of cooperative federalism with federal regulatory floors preempting any more lax state regulation, and federal oversight of state delegated programs - is really not necessary from a practical point of view and can be discarded without producing substantial environmental harm.

After setting forth the Clean Water Act's approach to delegated federalism, the chapter discusses the flawed nature of the data on which this claim is made. The experience of the 1960 simply does not support the argument in favor of devolution. This does not mean that every state was retrograde in its protection of water quality. The chapter, therefore, will also look at the progressive approach taken by some states, while also focusing on the action of the federal government during the 1960 s to improve water quality. Nevertheless, the best evidence we have indicates that water quality was not improving nationwide before the enactment of the Clean Water Act. In contrast to that level of performance, the Clean Water Act has produced considerable progress; progress, however, that would surely be jeopardized should the nation revert to the regulatory paradigm of the 1960 s. The true story reveals substantial benefits from federal regulation within a structure that preserves room for state participation, creativity, and even greater stringency. 


\section{THE CLEAN WATER ACT'S APPROACH TO DELEGATED FE,DERALISM}

In the fall of 1972, Congress enacted one of the most revolutionary statutes in history - the Clean Water Act. The act cast aside an earlier program that had relied almost exclusively on state agencies to adopt and implement waterquality standards. In Congress's view, that program had failed due to the reluctance of many states to adopt acceptable standards and appropriate implementation plans. Congress was also exercised by what some characterized as the near absence of enforcement. So in place of nearly exclusive reliance on state water standards, Congress adopted a radically new concept and applied it to ters of thousands of water polluters. The new strategy was predicated on the federal establishment of uniform, technology-based performance limitations.' These limitations, in turn, were to be applied to point-source dischargers ${ }^{2}$ through a new permit system that would specifically define the legal obligations of nunicipal and industrial dischargers. ${ }^{3}$ The state water-quality standard program was retained, however, to supplement the technology-based limitations in cases where such a uniform approach was not adequate to meet specific water-quality objectives, ${ }^{4}$ Although the newly established U.S. Environmental Protection Agency (EPA) issued many of the initial permits, state agencies could obtain, and the vast majority of them have obtained, authority to administer the permit program within their borders. ${ }^{5}$ Hence, the Clean Water Act's structure is not just federal but also involves overlapping and intertwined federal and state roles. All fifty states, moreover, enjoy the freedom to establish and enforce regulations that are more protective of the environment than EPA would require.

Although this kind of delegated program federalism is commonly referred to as "cooperative federalism," the fact remains that EPA is the senior partner

133 U.S.C. $\int S 1311(b)(2)(A),(b)(1)(B),(b)(2), 1316(b)(1)(B)$.

$=$ The act defines point sources as "any discernible, confined and discrete conveyance" such as pipes, conduits, ditches, and the like "from which pollutants are or may be discharged." 33 U.S.C. $\int 1362(14)$.

333 U.S.C. $\int 1362$ (creating the National Pollutant Discharge Elimination System [NPDES] permit system).

433 U.S.C. $\int 1313,131(b)(1)(C)$. The application of water-quality-driven permit conditions depends on the existence and subsequent administrative recognition of monitoring data indicating that a particular water is water-quality impaired. See generally, Oliver A. Houck, The Clean Water Act TMDL. Program: Law, Policy, and Implementation 5 (Washington, D.C.: Environmental Law Institute, end ed., 2002) (recounting the paucity of both data and political will).

533 U.S.C. $\{1362$ (b). Currently, forty-five states possess the authority to issue NPDES permits. 
in most aspects of the relationship. In addition to setting uniform effluent standards, EPA is given veto power over state-issued permits, ${ }^{6}$ the power in extreme instances to withdraw state permitting authority, ${ }^{7}$ the power to review and disapprove state water-quality standards, ${ }^{8}$ concurrent enforcement author ity, ${ }^{9}$ and the power to shape state programs through the provision of federal financial assistance ${ }^{10}$ and the promulgation of EPA's program regulations. ${ }^{11}$ Congress thus placed primary authority for policy creation and standard setting in the hands of EPA, making the federal government the dominant authority in an area in which state agencies had long held sway. Congress, however, did reserve a significant role for the states and many local governments to play.

In addition to permitting, states establish their own water-quality standards, ${ }^{12}$ are responsible for implementing those standards through the establishment of waste load allocations, ${ }^{13}$ are responsible for establishing programs to combat nonpoint-source pollution, ${ }^{14}$ and take the majority of enforcement actions. ${ }^{15}$ Many local governments, furthermore, have a vital role to play in the implementation and enforcement of the pretreatment program, which is designed to regulate industrial discharges to municipally owned wastewater treatment facilities. ${ }^{16}$ State and local governments may also adopt additional measures that directly or through incentives provide additional protection of their waters. This reservation of authority is found in the act's approach to federal preemption.

The Clean Water Act only expressly preempts less stringent state and local requirements, not more stringent ones. ${ }^{17}$ Through this kind of floor preemption, Congress expressly gave states and their political subdivisions the latitude to adopt limitations and other requirements that are more stringent than federal limitations and requirements. They can thus be more protective if they wish to be. The act's floor preemption is endowed with additional punch by virtue of a certification provision that gives states with water-quality concerns the power to veto or impose conditions on a wide variety of federal

633 U.S.C. $\$ 1362$ (d).

733 U.S.C. $\{1362(\mathrm{c})$.

83 U.S.C. $\$ 1313(\mathrm{C})(3),(4)$.

933 U.S.C $\$ 1319$.

1033 U.S.C. $\$ 1256$.

17 40 Code of Federal Regulations Part 123 (2006) (setting forth the requirements of state permitting programs under the Clean Water Act).

1233 U.S.C. $\{1313$ (c).

1333 U.S.C. $\int 1313(\mathrm{~d})$

1433 U.S.C. $\$ 21329$

is William L. Andreen, "Motivating Enforcement: Institutional Culture and the Clean Water Act," Pace Environmental Law Review 24, 170. 1 (2007): 67, 74-5.

16 40 Code of Federal Regulations Part 403 (2006).

1733 U.S.C S 1370. 
licensing activities. ${ }^{18}$ Another considerable reservation of state prerogative is found in the act's savings clause. This provision preserves "any right which any person (or class of persons) may have under any statute or common law to seek enforcement of any effluent standard or limitation or to seek any other relief." By virtue of the savings clause, citizens can use state common law tort actions to obtain damages for their own injuries while also encouraging, sometimes requiring, dischargers to reduce the kind or amount of pollution they discharge. ${ }^{20}$

\section{THE STATES AS LABORATORIES OF DEMOCRACY}

The states, however, infrequently adopt more stringent regulatory standards for water pollution. ${ }^{21}$ At least twelve states have enacted legislation either forbidding their programs from promulgating standards that are tougher than federal minimum requirements or imposing additional procedures that must be satisfied before such requirements become effective. ${ }^{22}$ Many states have also often been slow to utilize the authority that Congress reserved to them. Most, for example, have been reluctant to establish waste load allocations that are necessary for the implementation of water-quality standards. ${ }^{23}$ In addition, many states have chosen nonregulatory and often-ineffective approaches for the control of nonpoint-source pollution. ${ }^{24}$ Even state enforcement efforts have been declining for more than a decade. ${ }^{25}$ Instances where

1833 U.S.C. $\$ 1341$

19) 33 U.S.C S $1365(\mathrm{e})$.

20 Alexandra B. Klass, "Cormon Law and Federalism in the Age of the Regulatory State," Iowa LAW REview 92, no. 2 (2007): 545. Although the Clean Water Act has been held to preempt the federal common law of nuisance (M1LwaukEe V. ILLINOIS, 451 U.S. 304, 313-15 [1981]), litigants may seek relief under the common law of the state where the polluter is located. International Paper Co. v. OUelette, 479 U.S. 481,497 (1987).

21 Daniel P. Selmi and Kenneth A. Manaster, I STATE ENvironmental LAW S 11:12 (Eagan, MN: Thomson/West, 2006).

22 Yerome M. Organ, "Limitations on State Agency Authority to Adopt Environmental Standards More Stringent than Federal Standards: Policy Considerations and Interpretive Problems," Maryland Law Rleview 54, no. 4 (1995): 1373, 1376-86.

${ }^{23}$ Houck, The Clean Water Act 'TMDL Program, 63; Linda A. Malone, "The Myths and Truths that Ended the 2000 TMDL Program," PACE ENvironmental Law Review 20, no. 1 (2002): 63, $7^{8-81}$.

24 Willian L. Andreen, "Water Quality Today - Has the Clean Water Act Been a Success?" Alabama LaW Review 55, 10. 3 (2004): 537,545 n. 42 .

2.5 Andreen, "Motivating Enforcement," 75. In contrast to the Clean Water Act, which empowers private citizens to enforce its requirements, less than half of the state programs do, and of those that do, only one-third allow costs to be shifted in favor of a successful, injured plaintiff, James R. May, "The Availability of State Environmental Citizen Suits," NAturar REsources and IENVIRONMENT 18, no. $4(2004): 53,55-6$. 
states have vetoed or conditioned a federal license on water-quality grounds are relatively rare.

One might well conclude that many of these states are engaging, at least in part, in a race to the bottom in order to attract and retain industry through weaker environmental standards, lax implementation, and lethargic enforcement. ${ }^{26}$ Such economic development concerns resonate deeply in many, if not most, state capitals because state politicians generally lack access to any other macroeconomic instruments that can deliver such material benefits to their constituents. ${ }^{27}$ Another significant governor on the vigor of state environ. mental management efforts may be simple ideological hostility to regulation or the existence of a strong preference for voluntary, private efforts to control water pollution. State environmental agencies, however, may just be reluctant to do battle with entrenched economic interests, interests that in many, if not most, instances wield far more power in state capitals than relatively weak state bureaucracies. ${ }^{28}$

A number of states have taken advantage, at least occasionally, of the power that floor preemption gives them and have forged ahead with innovative approaches to some envirommental problems. The most notable recent example of this type of state action involves climate change. Due to the reluctance of the federal government to regulate greenhouse gases (GHGs) such as carbon dioxide, about one-third of the states have enacted new legislation or implemented executive orders designed to reduce the generation of GHGs within their borders. ${ }^{29}$ With regard to water pollution, perhaps the most obvious examples of more protective state action are found in a number in water-quality certification cases. In PUD No. 1 of Jefferson County $v$. Washington Department of Ecology, the Supreme Court upheld the state of Washington's imposition of a minimum stream-How requirement as a condition precedent to the issuance of a federal license for the construction of a new hydroelectric dam. ${ }^{30}$ More recently, the Supreme Court upheld a state

${ }^{26}$ Kirsten Engel, "State Euvironmental Standard-Setting: Is There a Race and Is It "To the Bottom"? Hastings Law Journal 48, no. 2 (1997): 271.

27 Timothy Doyle and Aynsley Kellow, Environmental Politics and Policy-Making in Australia 129 (Melbourme, Austratia: Macmillon, 1995).

28 Peter Grobosky and Johı Braithwaite, Of Manners Gentle: Enforcement Strategues of Australian Business Regulatory Agencies 207 (Melboume, Alistralia: Oxford University Press, 1986) (fnding a more cooperative regulatory approach among agencies that deal with smaller numbers of regulated entities).

29) Kirsten H. Engel and Scott R. Saleska, "Subglobal Regulation of the Global Commons: The Case of Climate Change," Ecology Law Quarterly 32, 130. 2 (2005): 183, 185; Barty G. Rabe et al., "State Competition as a Source Driving Climate Change Mitigation, NEw York UNIVERSITY ENVIRONMENTAL LAW JOURNAL 14, no. 1 (2005): 1, 8-11.

3o 5il U.S. $700,709-10(1994)$. 
certification for the federal relicensing of five hydroelectric dams on Maine's Presumpscot River that not only stipulated minimum stream fows but also required passage around or through the dam for migratory fish and eels, ${ }^{31}$ In the aftermath of another Supreme Court case, this one reducing the jurisdictional scope of the Clean Water Act, ${ }^{32}$ a number of states took some action to ameliorate the resultiing jurisdictional void. ${ }^{33}$

So the states can serve and many have served, from time to time, as "laboratories of democracy." 34 In doing so, these states have filled various regulatory gaps left by the federal government. They have also, through their trial-and. error experimentation with new approaches, created models worthy of emum lation by other jurisdictions. Congress based the citizen suit provision found in the $197^{\circ}$ Clean Air Act on an earlier Michigan statute, and the concept of using water pollution permits in the Clean Water Act had its origin in the systems created by a number of states. State establishment of more stringent requirements, however, often provokes a backlash among the economic and industrial powers whose interests have been adversely affected. Thus, the victory that the state of Washington enjoyed in setting minimum flow conditions in PUD No. 1 led the Republican-dominated House of Representatives in 1995 to pass a bill that would have deprived states of this authority. ${ }^{35}$ Many of the chapters in this book discuss recent legislative and regulatory actions that similarly attempt to impose federal limits or ceilings on state action.

\section{DEVOLUTION?}

The debate about the appropriate approach to federalism in water pollution control does not only involve the question of precluding more protective action by state government and state courts. The most common debate about the appropriate distribution of power between the states and the federal govermment in this policy arena has focused on whether the federal government should have a primary role to play, aside perhaps from the provision of financial and technical assistance to the states and dealing with the spillover effects of interstate pollution. Richard Revesz, for instance, has argued that federal environmental statutes that set regulatory foors hobble state efforts to craft

31 S.D. Warken Co. v. Maine Bonkd of Environmental Protection, 126 S.Ct. 1843,2847 (2006).

3. Sol.to Waste Agency of Northern Cook County v. Army Corps of Engineers, 531 U.S. 159, 171 (2001).

33 Michael f. Gerhardt, "The Curious Flight of the Migratory Bird Rule," Environmental LAW REPORTER 31, no. 9 (2001): 11,079, 11,085.

34 New State Ice Có. v. Llebmann, 285 U.S. 262, 311 (1932) (Brandeis, J., dissenting).

35 "State Authority to Ensure Water Quality under Attack," American Rivers 23, no. 2 (2995): 5. 
regulatory regimes that meet their own conceptions of the public good. $3^{6}$ Thus, if they are constrained from competing over environmental regulation because it has been nationalized in part, they will be forced to compete in other ways such as by offering lax standards in other regulatory areas or by providing various financial incentives to industry. ${ }^{37}$ In a different vein, Jonathan Adler has contended that a reduced federal presence could enhance the effectiveness of environmental regulation by increasing the need for innovative state reforms. ${ }^{38}$ More specifically, Adler has suggested that federal regulatory floors can actually discourage more stringent or wiser state action by either signaling that state action is unnecessary or by "crowding out" the need for state action. ${ }^{39}$

Thuse who favor a more decentralized approach to environmental regulation - a devolution of authority from the federal to the state level - often point to commentators who claim that the states were actually making significant environmental progress prior to the 1970 and the enactment of the modem federal pollution-control statutes. Although most of these commentators focus on our nation's experience with two air pollutants, particulate matter and sulfur dioxide, ${ }^{\circ}$ one of these commentators looked at water pollution. After examining reports discussing EPA's first national water quality inventory, which was issued in 1974, A. Myrick Freeman concluded that "there had been significant improvements in most major waterways" during the 1960 " at least in regard to organic wastes and bacteria." 4 Adler, in turn, based on Freeman's work, has argued that this evidence "suggests that states began addressing those water quality problems that were clearly identified and understood well before the federal government." ${ }^{\prime \prime 2}$ History, therefore, demonstrates the

${ }^{36}$ Richard L. Revesz, "Rehabilitating Interstate Competition: Rethinking the 'Race to the Bottom' Rationale for Federal Environmental Regulation," NEW YORK UNIVERSITY LAW Review, 67, no. 6 (1992); 1210 .

37 Richard L. Revesz, "The Race to the Bottom and Federal Environmental Regulation: A Response to Critics," Minnesota Law Review 82, no. 2 (2997): 535, 54 :.

$3^{8}$ Jonathan H. Adler, "Judicial Federalism and the Future of Federal Environmental Regulattion," lowa law Review go, no. 2 (2005): 377, 464.

39 Jonathan H. Adler, "When Is Two a Crowd? The Impact of Federal Action on State Euvironmental Regulation," Harvard Environmental LaW Review 31, no. 1 (2007):67,94-9.

40 Indur Goklany, Clearing the Air: The Real Story of the War on Alr Pollution (Washington, D.C.: Cato Institute, 1999), 49-56; Paul R. Portnoy, "Air Pollution Policy," in Public Pozicies for Environmental Protecrion, ed. Pall R. Portnoy and Robert N. Stavins (Washington, D.C.: Resources for the Future, 2000), 77; Robert W. Crandall, CoNtrolling Industrial Pollution: The Economics and Politics of Clean Air (Waslyington, D.C.: Brookings Institution, 1983), 19.

41 A. Myrick Freeman, "Vater Pollution Policy," in Public Policies ron Environmental Protection, ed. Paul R. Portnoy and Robert N. Stavins (Washington, D.C.: Resources for the Future, 2000), 187 .

42 Adler, "Judicial Federalism," 465. 
"environmental benefits of decentralization" and provides "ample reason to question the assumption that lessening federal environmental regulatory authority necessarily results in lessened environmental protection." ${ }^{33}$ Hence, our present reliance on delegated federalism is unnecessary and federal power can be curtailed without producing negative environmental ramifications.

Such claims must be closely scrutinized against the historical record for any substantial change in our current regulatory paradigm could seriously undermine the effectiveness of our national effort to obtain and maintain clean and healthy waters. The question is not whether or not we are going to permit state experimentation. State experimentation is clearly available under the current approach to preemption, an approach that permits states to innovate and institute new policies as long as they do not fall below minimum environmental standards. The question, rather, is whether we are willing to remove that floor, that safety net, and permit states to pursue policy initiatives that fall below those minimum requirements.

A careful examination of the 1974 EPA report, ${ }^{44}$ reveals no historical support for the broad contentions that have been based on it. Although it does conclude that some improvement had occurred with respect to a few water pollutants, the report cannot be considered a comprehensive assessment of progress in the fight against water pollution. The report is flawed in many ways, reflecting, no doubt, the complexity of attempting to detect trends in water quality. The EPA, for example, did not attempt to control for variations in stream flow, a factor that strongly affects concentrations of organic pollutants due to the impact of dilution. The monitoring stations, from which the data was drawn, moreover, were not held uniformly constant - thereby injecting a degree of ambiguity into many of the report's conclusions. In short, EPA's report is not good evidence that water pollution was improving nationwide during the ten years prior to the enactment of the Clean Water Act, and it lends no support to the claim that federal authority can be reduced today without incurring adverse environmental impact.

Water quality, however, was improving in some locations in the years leading up to 1972. This progress was largely the result of the construction and upgrading of a number of municipal wastewater treatment facilities. These local improvements, however, were not exclusively the product of state and local action because the federal government was also active in some waterpollution control activities in the 1960 and early 1970s. During those years, the federal program was providing funding, albeit at inadequate levels, for the

43 Ibid., $464-5$.

44 U.S. Environmental Protection Agency, "National Water Quality Inventory" (1974). 
construction of municipal sewage treatment plants; pushing state agencies to adopt water-quality standards, antidegradation policies, and adequate implementation plans; and involved in a number of enforcement actions. ${ }^{45}$

Nevertheless, the best data we have indicates that the overall quality of the nation's waters was not improving at this time; to the contrary, the situation appears to have been growing worse. Not only had the earlier federal program been inadequate to the task, but state efforts had been also. It was time, therefore, to institute a wholly new approach, an approach that has produced remarkable progress over the past thirty-five years.

\section{A CLOSER LOOK AT THE 1974 EPA REPORT}

The Clean Water Act requires each state to prepare a biennial report on the condition of its water quality and its progress toward achieving the act's goal of fishable and swimmable waters. The EPA, in turn, must transmit these reports to Congress along with the agency's analysis of the state results. ${ }^{46}$ The EPA's 1974 section 305 (b) report, however, could not rely on state submitted data because the states had not had time in the short period following the passage of the act to collect the stream quality and effluent data on which their reports would depend. The EPA, therefore, prepared the 1974 report using its STORET (storage and retrieval) database to try to analyze national trends in water quality during the previous decade. ${ }^{47}$ In doing so, EPA relied on data from 1,300 monitoring stations located along twenty-two waterways in an effort to discern what if any changes in water quality had occurred between the period of $1963-7$ and that of $1968-72 .{ }^{48}$ Because many of these stations did not collect data throughout the duration of the study period, EPA often substituted data from stations located elsewhere along that particular waterway, 49 adding a variability that substantially lessens the confidence that one might otherwise have in the trends the report claims to have detected..$^{\circ}$

45 William L. Andreen, "The Evolution of Water Pollution Control in the United States - State, Local, and Federal Efforts, 1789-1972: Part II," Stanford Environmental Law Journal 22, no. 2 (2003): 215, 239 $-42 ; 249,252-5$.

${ }_{46} 33$ U.S.C. $\int 1325(\mathrm{~b})$.

47 U.S. Environmental Protection Agency, "National Water Quality Inventory" (1974), 1, 9. EPA's STORET database, first developed in 1964 , is one of the most venerable environmental database systems still in use. Maintained by the agency's Office of Wetlands, Oceans, and Watersheds, STORET contains data from ambient water-quality monitoring stations, effuent monitoring, and intensive surveys. U.S. Environmental Protection Agency, "National Water Quality Inventory 1996," 38 .

$4^{8}$ U.S. Environmental Protection Agency, "National Water Quality Inventory" (1974), 13.

49 Ibid., 13, 72, 110, 133.

so Ibid, 110 . 
According to the report, there had been "general improvements" in organic pollution, bacteria, ammonia, and suspended solids. ${ }^{51}$ Organic pollution, commonly measured as biological oxygen demand (BOD), had apparently improved in 74 percent of the river segments that were analyzed, producing improved dissolved oxygen (DO) levels on 61 percent; bacteria levels had improved on 58 to 78 percent; ammonia on 76 percent; and suspended solids on $8 z$ percent. Nevertheless, EPA noted that bacteria levels and suspended solids remained at persistently high levels. In addition, EPA reported significantly worsening trends for two nutrients - nitrogen and phosphorus. Concentrations of total phosphorus had apparently increased in 82 percent of the river segments and nitrates in 74 to 76 percent. ${ }^{52}$ Overall, EPA concluded that more stream segments had become moderately polluted during the decade, although fewer were heavily polluted. But the vast majority of the thirty-six river segments that were assessed appear to have been in violation of EPA waterquality guidelines for at least one pollution parameter in the period of $1968-72$ and more than 60 percent were in violation of eight or more parameters. ${ }^{53}$

The limitations of the report were recognized at the time. The Council on Environmental Quality (CEQ) urged that the report "should be interpreted with caution" because, among other things, $\mathrm{DO}$ concentrations fluctuate with stream flow and temperature. ${ }^{54}$ The concerns expressed by CEQ were well founded. The Northeast, Mid-Atlantic, Midwest, and Central states had all experienced widespread drought conditions from 1963 to 1966,55 thus overlapping with three of the four years in EPA's initial snapshot of the nation's water quality. Low precipitation produces lower flow conditions, and lower flows produce the highest concentration of organic pollution and thus the lowest levels of DO. ${ }^{56}$ By contrast, the years between 1968 and 1972 were not

51 Ibid., z2.

52 bid.

53 Ibid, 24-5. It would be impossible to accurately compare the waters violating EPA guidelines in 1974 with those that are classified as violating the guidelines in later years because many of the reference points have been strengthened to better protect human health and the environment. In 1974, for example, EPA used a reference point of $4.0 \mathrm{mg} / \mathrm{l}$ for $\mathrm{DO}$ (for fish and wildhfe) and 2,000 fecal coliforms per $100 \mathrm{ml}$ (for recreation). U.S. Environmental Protection Agency, "National Water Quality Inventory" (1974), 24-5. In 1976, those criteria were strengthened to $5.0 \mathrm{mg} /$ and 200 fecal coliforms per $100 \mathrm{ml}$, respectively. U.S. Environmental Protection Agency, "Quality Criteria for Water" (1976), 42, 123. Subsequent revisions are found in U.S. Euvironmental Protection Agency, "Quality Criteria for Water" (1986), 42m-50, 209-19.

54 Council on Environmental Quality, "Fiftl Annual Report" (1974), 287.

55 Andrew Stoddard et al., Municipal Wastewater 'Treatment: Evaluating ImproveMEN'TS IN Na'tronal. Water QUality (New York: John Wiley and Sons, 2002), 111; U.S. Environmental Protection Agency, "National Water Quality Inventory" (1974), 104 (acknow)edging that the period 1968-72 was much wetter than $1963-7$ in the Ohio River watershed).

56 Stoddard, Municipal. Was'tewater Treatment, 108-11. 
years characterized by widespread drought, ${ }^{57}$ and hence one would expect lower concentrations of organic pollution and higher levels of DO.

Because a major variable was not held constant, it would stretch credibility to conclude that levels of organic pollution in the nation had actually improved over the course of the 1960 s. A recent EPA study indicates that the effluent loading of organic pollutants from municipal wastewater treatment facilities had actually increased 8 percent between 1962 and $1972 . .^{8}$ Therefore, what EPA may have been comparing, at least to some extent, was the impact of dilution on discharges of municipal waste, which typically contains organic material, bacteria, and ammonia. ${ }^{59}$ That would explain much of the observed "improvement" in those parameters. The impact of increased dilution would also have minimized the contribution of organic discharges from industry, which, as the next section explains, were nearly equal to the contribution from the municipal sector.

The improvement in suspended solids, however, cannot be attributed to higher stream flows because one would expect suspended solids to rise with higher flows due to greater runoff and the scouring of sediment and silt from stream bottoms. Rivers are simply more turbid, as a general matter, during high flows than during low flows. Thus EPA's report suggests a striking improvement in concentrations of suspended solids. The EPA attributed the improvement to many factors. In its detailed discussion of the Ohio River, for instance, EPA stated that the downward trend along the river may have been due to the fact that the same monitoring stations were not being relied on during both periods of time. At stations that were measured during both time periods, levels of suspended solids were actually increasing. ${ }^{60}$ The introduction of new high head dams may also account for part of the observed improvement, ${ }^{6}$ and higher flows and increased velocity may actually improve turbidity levels in some rivers. ${ }^{62}$ At any rate, the overwhelming majority of suspended solids in our nation's waters result from nonpoint-source discharges - erosion from agricultural fields, construction sites, mining operations, logging activities, and urban runoff; discharges that went virtually unregulated during those years. If there was any improvement

57 Ibid., 554-8.

58 Ibid., 477 .

59 One would expect runoff related pollutants, such as bacteria from animal feeding operations, to increase during periods of high precipitation. Such increases in rural areas, however, may not have offset the broad-scale dilutional impact that increased flows had on bacteria discharged by urban sewerage systems.

6o U.S. Environmental Protection Agency, "National Water Quality Inventory" (1974), no.

6. Ibid. (referring to new dams along the Ohio).

62 Ibid., 72 (referring to the lower Mississippi River). 
with regard to suspended solids, it is unlikely that much of it was the result of state regulatory action.

The more widespread use of wastewater treatment technology (especially primary treatment where solids are removed from raw sewage) by the nation's cities and towns did produce lower discharges of suspended solids from that point-source category. The EPA has recently concluded that discharges of suspended solids from publicly owned sewage treatment plants decreased 9 percent between 1962 and $1972 .{ }^{63}$ This decrease, however, was likely undetectable because it would have been dwarfed by the combined level of suspended solids from industry ${ }^{64}$ and nonpoint sources.

\section{AN EVALUATION OF PROGRESS IN THE DECADE PRIOR TO ENACTMENT OF 'THE CLEAN WATER ACT'}

Although EPA's 1974 report does not appear to be a reliable barometer of an improving trend in national water quality, there is no doubt that some progress was being made in the years before the Clean Water Act was passed. That progress - generally limited to specific streams in particular states or regions was primarily, but not exclusively, the result of state and local action.

The state of Oregon, for instance, made great strides in cleaning up the Willamette River, a river that had been known as the filthiest stream in the Northwest. As the result of state action, all of the municipalities discharging to the river implemented primary treatment, which removes about 30 percent of organic waste, between 1949 and 1957. In 1960, the state increased the requirement for these municipal facilities to secondary treatment, which removes approximately 85 percent of organic waste, and, in 1967 , it extended the secondary treatment requirement to industrial dischargers. As a result, by 1972 BOD discharges by point sources to the river had dropped 75 percent from 1957 levels. ${ }^{65}$ Nevertheless, bacteria counts still violated standards more often than not, and toxic discharges from the paper and pulp industry remained high in the lower eighty miles of the river. ${ }^{66}$

$6_{3}$ Stoddard, National WaTer Qualtry, 481 .

64 Discharges of suspended solids from industry in 1973 amounted to approximately 898,010 metric tons per day compared to 7,531 metric tons per day from municipal wastewater treatment plants. Ibid., 589 .

65 Ibid., 405-6. In response to the federal Water Quality Act of 1965 , Oregon established intrastate and interstate water-quality standards in 1967 , standards that were among the first of the new state standards to be approved by the federal government. Ibid., 405. The federal government also provided millions of dollars for the construction and upgrading of municipal wastewater facilities along the Willamette between 1956 and 1972.

66 U.S. Envirommental Protection Agency, "National Water Quality Inventory" (1974), 235. 
Although the Twin Cities of Minneapolis and St. Paul constructed a primary treatment facility in 1938 , increased discharges associated with population growth had overwhelmed the assimilative capacity of the Mississippi River by the ig6os. According to the Federal Water Pollution Control Administration, which studied this section of the Mississippi in 1964, the river bottom for twenty miles was "thick with sewage sludge" and devoid of the organisms associated with a healthy stream. ${ }^{67}$ Not surprisingly, the water was low in DO and high in bacteria. The bleak situation prompted local officials to upgrade the Twin Cities facilities to secondary treatment in 1966, an action that immediately improved water quality below the plant. However, 88 percent of the suburban sewage treatment plants in the Twin Cities metropolitan area persisted in discharging inadequately treated waste to the Mississippi River, ${ }^{68}$ bacteria counts remained high, and DO occasionally fell to extremely low levels. ${ }^{69}$

Along the Delaware River, most municipal sewage plants above Philadelphia had installed secondary treatment by 1960 . Below Philadelphia, however, DO levels remained abysmally low. ${ }^{70}$ In Chattanooga, improvements to the sewage treatment plant rendered the Tennessee River suitable for recreation downriver, except for areas immediately downstream of the plant and along the city's waterfront. ${ }^{71}$ Many other waterways, such as the James River, the Potomac River, the Connecticut River, and large stretches of the Chattahoochee River, remained grossly polluted. ${ }^{72}$ The progress that had been made was, unfortunately, neither national in scale nor comprehensive in nature.

Much of the progress that was made, moreover, was due to federal efforts. Of the nearly $\$ 5.3$ billion that was spent on the construction of sewage treatment facilities during the 1960s, $\$ 1.1$ billion came from the federal government. ${ }^{73}$ Although the federal contribution may have amounted to only a fifth of the total amount spent, the existence of this federal grant program

${ }^{67}$ Stoddard, National, WaTer Qualtry, 369.

68 lbid., 368-9.

69 U.S. Envirommental Protection Agency, "National Water Quality Inventory" (1974), 73, 76

70 Stoddard, National. Water Quality, 262.

7 U.S. Environmental Protection Agency, "National Water Quality Inventory" (1974), 140. The Temessee River had been the focus of some federal enforcement attention during the 19605 and had been listed as the subject of a potential enforcement conference as early as 1963 . Stoddard, Municipal. Wastewater Trentment, 419.

72 Stoddard, Municipal. Wastewater Treatment, 204-5, 285, 316, 334.

73 U.S. Environmental Protection Agency, "The Cost of Clean Water, Volume II: Cost Effectiveness and Clean Water" (1971), 19. Federal expenditures on the construction grants program would have been nearly twice as large in the 1960 , but the program's funding fell victim to the cost of fighting the Vietnam War. Andreen, "Evolution of Water Pollution Control: Part Il," 252 (relating that $\$ 750$ million of the sums authorized for expenditure in 1968 and 1969 were never appropriated). 
created an incentive that often prompted state and local governments to invest in their infrastructure. ${ }^{74}$ As a result of these state, local, and federal efforts, the number of municipal treatment facilities providing secondary treatment rose from 6,719 in 1962 to 13,893 in $1972,{ }^{75}$ Unfortunately, the number of sewer systems providing no treatment remained stationary - rising marginally from 2,262 to 2,265 - while the number of systems providing only primary treatment fell slightly from 2,717 to $2,530 .^{76}$ Despite the expansion of efforts during the 1960 s to build modern treatment facilities for municipal waste, the amount of sewage discharged with inadequate treatment (less than secondary) remained essentially unchanged at 9,375 million gallons a day (MGD) in 1972 compared with 9,372 MGD in 1962-although the amount discharged without any treatment did fall by 1,594 MGD. In terms of organic material discharged from these facilities, the nation was losing ground. The discharge of organic pollu* tants from the nation's sewer systems grew from 11,765 metric tons per day in 1962 to 12,558 metric tons per day in $1972 .{ }^{77}$ That rise might account, at least in part, for the results of a CEQ-contracted study that found that oxygendemanding water pollution had grown, primarily in urban areas, between 1965 and $1970 .^{78}$

Much responsibility for that apparent growth, however, must be borne by industry as well. In 1973, industry was responsible for approximately 43 percent of the sewered oxygen demand in U.S. waters. ${ }^{79}$ Industry's overall contribution to the pollution of the nation's waterways, moreover, was staggering representing roughly 63 percent of all wastewater discharged by point sources

${ }^{74}$ According to the Associate Director of the U.S. Conference of Mayors, approximately lialf of the money that state and local government contributed to this effort was stimulated by the availability of federal grant money. Water Pollution Control: Hearings before a Special Subcommittee of the Senate Committee on Public Works, 88th Cong. 93 (1963) (testimony of Hugh Mield Jr.). In addition, some state and local actions were no doubt spurred by the publicity generated and recommendations issued by some fifty-one federal-enforcement conferences that were convened between 1957 and 1970. Water Pollution Control Legislation, 1975: Hearings before the House Committee on Public Works, gad Cong. 179 (1971) (statement of John Quarles, General Counsel of EPA, recounting the spotlight which the conferences shone on persistent water-pollution problems).

75 Stoddard, National. Water Quality, 458.

$7^{6}$ Ibid.

77 Ibid., 469 . Because the influent of organic material had grown during the decade, the overall removal efficiency, however, had improved from 38.3 percent to 45 percent. Ibid., 470 .

$7^{8}$ Council on Environmental Quality, "Third Annual Report" (1972), 33. The study, performed by Ënviro Control, Inc., made some corrections to account for flow variations. However, due to a limited number of monitoring locations from which the data was drawn, the study did "not represent a complete and properly weighted cross section of all U.S. waters." Ibid.

79 Stoddard, Municipal WasteWATER TREATMENT, 588. A much earlier EPA study, however, estimated that industry was responsible for nearly 80 percent of sewered oxygen demand in 1968. U.S. Envirommental Protection Agency, "The Cost of Clean Water, Volume II," 64. 
into waters of the United States. ${ }^{80}$ As late as 1968 , some 70 percent of the annual industrial discharge of more than 14 trillion gallons of wastewater received absolutely no treatment whatsoever, ${ }^{81}$ and much of the rest enjoyed only rudimentary treatment. ${ }^{8 z}$ The amount of untreated industrial effluent, moreover, increased at an annual rate of 1.6 percent between 1964 and $1968,{ }^{83}$ while the overall percentage of industrial waste treated to one extent or another improved only modestly from 29.2 percent to 30.4 percent. $^{8.4}$

The nation, in short, appears to have been losing ground in its struggle with water pollution. The amount of industrial waste that received treatment remained ridiculously low, and the amount of untreated industrial effluent was growing. Meanwhile, the amount of organic waste being discharged from municipal facilities was still rising. In 1969, 41 million fish were killed by water pollution, the highest number of fish deaths reported since an annual census had begun in $1960,{ }^{85}$ but a record broken in 1971 when nearly 74 million fish were killed in U.S. waters. ${ }^{86}$ Other examples of foul-smelling, repulsive water conditions appeared year after year. ${ }^{87}$ It was no surprise in 1971 , therefore, when the federal government announced that a substantial portion of U.S. waters were "persistently polluted" 88 - waters that consistently violated established water-quality criteria. ${ }^{89}$

80 In 1968 , municipal sewer systems discharged 23,116 million gallons of wastewater per clay (Stoddard, Municipal Wastewater TReatment, 460) or 8,437 billion gallons per year. By contrast, a total of 14,276 billion gallons of wastewater were discharged in 1968 by large manufacturing facilities - defmed as those facilities using more than 20 million gallons of water per day. U.S. Environmental Protection Agency,"The Economics of Clean Water, Volume 1" (1972), 20. This comparison, therefore, is a rough one, not only because small, medium, and fairly large manufacturing plants were not included in the industrial discharge statistic but also because approximately 7 percent of the waste that was disposed of by the surveyed "large" industrial facilities was discharged to municipal sewer systems. Ibid., 17.

$8:$ Ibid., $25,28$.

${ }^{82}$ William H. Rodgess Jr., "Industrial Water Pollution and the Refuse Act: A Second Chance for Water Quality," University of Pennsylvania Law Review 119, no. 5 (1971): 761,764 . According to E,PA, the absence of data at this time made it impossible to estimate "the degree of treatment received by final industrial waste discharge." U.S. Envirommental Protection Agency; "The Economics of Clear Water, Volume I," 28.

83 lbid, 28.

84 Ibid., 26

8s Federal Water Quality Administration, "1969 Fish Kills" (1969), 1.

86 U.S. Environmental Protection Agency, "Fish Kills Caused by Pollution: Fifteen-Year Summary $1961-1975^{\prime \prime}(1975), 5$.

${ }_{7}$ William L. Andreen, "The Evolution of Water Pollution Control in the United States - State, Local, and Federal Efforts, 1989-1972: Part I," Stanford Environmental, Law Journal 22, no. $1(2003): 145,197-8$.

${ }^{88}$ U.S. Environmental Protection Agency, "The Cost of Clean Water, Volume Il: Cost Effec. tiveness and Clean Water" (1971), 52.

89 bid., 55 . 


\section{THE IMPACT OF THE CLEAN WATER ACT ON WATER QUALITY}

In contrast to the stubbornly degraded conditions that dominated water quality in the 1960s, the Clean Water Act has produced real, substantial progress. An EPA-funded study that was conducted in the late 1990 found that municipal wastewater treatment plants discharged 23 percent less organic waste in 1996 than in 1968 , despite the fact that loadings of BOD (influent) had increased by 35 percent over the same period..$^{\circ}$ Over a shorter period of time (1973 to 1995), the amount of BOD discharged by industry fell by 40 percent. ${ }^{91}$ Even though a substantial portion of the decline in industrial BOD discharges can be linked to the fact that many industrial facilities shifted their discharges to municipal systems, the overall decline in $\mathrm{BOD}$ discharges is significant and can be attributed to the construction and renovation of thousands of municipal treatment facilities, ${ }^{92}$ as well as to the imposition and enforcement of technology-based effluent limitations. ${ }^{93}$

The most innovative aspect of this particular study, however, was its approach to assessing nationwide trends in ambient $\mathrm{DO}$ concentrations brought about by regulating pointusource discharges of BOD. The study examined DO levels before and after the passage of the Clean Water Act and evaluated changes in DO only for monitoring stations that were impacted by point sources; stations influenced solely by nonpoint sources were excluded. ${ }^{94}$ In an effort to isolate low-flow conditions (thus screening out the noise produced by seasonal variations in precipitation, flow, and temperature and minimizing the impact of nonpoint-source loadings), ${ }^{95}$ the monitoring data was limited to the months of July through September, and to represent comparable worst-case, low-flow conditions, two especially dry periods were chosen: $1961-5$ (before passage) and 1986 m1990 (after passage). ${ }^{96}$ The study was also intended to go beyond prior inquiries and determine whether

So Stoddard, Municipal WASTEWATER TREATMENT, 61 (measuring uitimate BOD of the carbonaceous and nitrogenous components of oxygen consumption).

91 In 1973, industrial discharges of BOD amounted to 5,406 metric tous per day compared to 3,243 in 1995. Ibid., 588,590 .

${ }_{92}$ Between 1970 and 1999 , the federal government provided $\$ 77.2$ billion for the construction of publicly owned treatment works, a sum that was combined with state and local expenditures of roughly the same magnitude. Andreen, "Evolution of Water Pollution Control, Part Il," 552.

${ }^{3}$ Stoddard, National Water Quality, 5-6.

94 Ibid., 122.

95 Ibid., 120.

96 Ibid., $107^{-21}$. 
point-source controls had only produced localized effects, as some previous reports had noted, ${ }^{97}$ or had actually produced broader stream improvement. ${ }^{98}$ The study, therefore, evaluated changes at three different scales: river reaches (small scale); catalog units (medium scale); and major river basins (large scale). ${ }^{99}$

Perhaps surprisingly, the investigators documented "significant improvements" in summer DO conditions at all three spatial scales. ${ }^{100}$ They found progress in more than two-thirds of the reaches, catalog units, and major river basins that they surveyed. Sixty-nine percent of the river reaches that were assessed (representing largely urbanized, industrial areas) experienced improved levels of DO. The reaches with the greatest increases saw improvements ranging from 4.1 to $7.2 \mathrm{mg} / \mathrm{L}$, and the percentage of reaches having worst-case, low-flow DO levels above the benchmark of $5.0 \mathrm{mg} / \mathrm{L}^{101}$ rose from 46 percent to 69 percent. In addition, 68 percent of the larger catalog units (again dominated by urban/industrial areas) enjoyed higher levels of DO. As with the smaller scale reaches, the percentage of catalog units with worstcase DO levels meeting or exceeding $5.0 \mathrm{mg} / \mathrm{L}$ also rose, this time from 53 percent to 74 percent. ${ }^{102}$ Finally, eight of the eleven major river basins that were examined enjoyed "statistically significant improvement," while the other three basins did not suffer significant degradation. ${ }^{103}$ According to the investigators, "Given the very large spatial scale of the major river basins, it is remarkable to observe statistically significant before and after DO improvements as detected using the systematic methodology [which we employed]." 104

Many water-quality problems remain, especially those linked to nonpointsource discharges, contaminated sediments, sewer overflows, hydrologic modifications, and habitat degradation. ${ }^{105}$ The evidence, however, is unambiguous; the initial regulatory strategy contained in the Clean Water Act has been successful. The application of technologybased limitations through the National Pollutant Discharge Elimination System (NPDES) permit system,

97 Debra S. Knopman and Richard A. Smith, "20 Years of the Clean Water Act," Environmenr 35, no. 1 (1993): 16, 34-5.

98 Stoddard, Munjcipal, Wastewater Treatment, 105.

99 Ibid., 7-10.

${ }^{100}$ Ibid., xvi.

10) Five mg/l is considered to be the dividing line between healthy and unhealthy levels of DO. Ibid., 6. However, the actual water-guality standards in a mumber of southern states permit DO excursions down to $4.0 \mathrm{mg} /$ during specifically defined low-flow conditions.

${ }^{102}$ lbid., 175.

${ }^{103}$ Ibid., 176 .

104 Ibid.

${ }^{105}$ Andreen, "Water Quality Today," 542-6, 564, 578-91. 
which allows for state participation, enforcement, and amplification, although not perfect, has largely lived up to its preenactment billing. Together with the expenditure of some $\$ 150$ billion on municipal wastewater treatment facilities, this classic form of command-and-control regulation within the structure of delegated federalism has produced astonishing improvements in water quality. The continuation of this success, however, is by no means assured. One of the oldest approaches to pollution control, state water-quality standards, still awaits ful] implementation. It is ironic that so many states, having expressed a strong preference for water-quality standards over technology-based limitations when the Clean Water Act was written, have proven so reluctant to impose water-quality derived restrictions on point sources and nonpoint sources. ${ }^{106}$ Another great challenge, albeit one that receives much less attention, is the future federal funding of municipal wastewater treatment facilities. Our growing population and aging infrastructure will likely reverse much of the progress we have made since the early 1970s unless many existing plants are upgraded and new, more sophisticated facilities constructed. ${ }^{107} \mathrm{~A}$ new and significantly enhanced federal commitment must be made and sustained, or many of our gains will be lost. ${ }^{108}$

\section{CONCLUSION}

Despite the efforts of state and local government, the fight against water pollution at the end of the 1960 was foundering. Insufficient resources had been committed to the construction of municipal wastewater treatment facilities, while the regulation of industry was in most cases nonexistent. Seventy percent of all industrial wastewater still received no treatment. State waterquality standards were often weak, and so were state enforcement programs. ${ }^{209}$ Even if the will to enforce were present, the general lack of monitoring data made proving or even learning of a water-quality violation difficult, and the nearly uniform lack of discharge-specific limitations made linking a violation to a specific polluter nearly impossible in many cases. ${ }^{110}$ The result was pervasive pollution and hundreds of impaired waters. One should, therefore, be wary of broad claims that state and local water pollution programs "were

${ }^{106}$ Houck, The Clean Water Act TMDL Program, 5, 63; Linda A. Malone, "The Myth and 'Truths that Ended the 2000 TMDI. Program," Pace Environmental Law Review 20, no. 1 (2002): 63, 78-81.

${ }^{107}$ Stoddard, National Water Quality, 99.

${ }^{108}$ U.S. Environmental Protection Agency, "The Clean Water and Drinking Water Infrastructure Gap Analysis (2002), 6, 14-15.

109 Andreen, "Evolution of Water Pollution Control, Part II," 252-5.

${ }^{10}$ Houck, The Clean Water act TMDL Program, 3 3. 
making environmental progress" in the ig6os. ${ }^{11}$ Although some programs were producing progress, the overall picture was dismal. "In the face of a growing population and rapidly expanding manufacturing activity, state regulatory efforts were proving too little, too late."112

That lack of general success cannot be ascribed entirely to state and local government. The federal government had been active in some aspects of water pollution control for decades, and the pace of its involvement was accelerating during the 1960 s with an expanded construction-grant program, a new water-quality standards program, and the use of section 13 of the Rivers and Harbors Act as a device in the struggle against water pollution. ${ }^{113}$ This expanded federal program, however, was clearly not equal to the task. Despite some increasing effort at the state, local, and federal levels and some success stories, the overall trend at the advent of the 1970 s was not encouraging. Relying on more of the same in the hope that state efforts "would pick up steam in the years to come"114 was a course that Congress, clearly annoyed with the growing degradation of our waters, rejected in 1972 .

Congress, therefore, charted a completely new regulatory course with the enactment of the Clean Water Act. The navigation of that new course has not been easy, and there have been and continue to be numerous pitfalls. However, the application of federal technology-based effluent limitations through the NPDES permit system has proven to have been a wise, initial course of action. Together with an expanded construction-grant program, the technology-based approach has produced tremendous reductions in the level of both industrial and municipal point-source pollution. More, much more remains to be done. But, we should recognize success, even partial success, when it occurs; and the credit for this success must be shared broadly.

It, nevertheless, must be recognized that the effort prior to 1972 was primarily a state effort, as it had been for decades. The overall failure of that approach stands in stark contrast to the success that we have witnessed under the Clean Water Act. Those results ought not to be forgotten whenever there are calls to deconstruct the Clean Water Act by stripping EPA of the authority to set and oversee the achievement of basic regulatory requirements. Such calls, which run counter to the lessons of history, need to be carefully and critically evaluated.

"Jonathan H. Adler, "Fables of the Cuyahoga: Reconstructing a History of Envirommental Protection," Fordham Environmental Law Journal 14, no. 1 (2002): 89, 138.

112 Andreen, "Evolution of Water Pollution Control, Part I," 196-7.

"3 Rodgers, "Industrial Water Pollution and the Refuse Act," 76x.

${ }^{214}$ Adler, "Fables of the Cuyahoga," 138. 
Part of the genius of the Clean Water Act, however, lies in its grant of authority to the states and state common law litigants to go further and seek protections that lie beyond the minimum requirements of federal law. Thus, the Clean Water Act permits states and state courts to pitch in and fill regulatory voids wherever the act fails to address modern environmental concerns or whenever EPA fails to adequately implement or enforce existing law. Such gap-filling actions, unfortunately, are not common enough. It seems as if many states would prefer not to vigorously enforce or implement even the basic requirements of the Clean Water Act. It is fortunate, therefore, that the basic federal floor requirements remain as part of a regulatory structure that has, despite its flaws and occasional poor leadership, served the nation well since 1972 . 